Dept. Theriogenology,

Fac.Vet. Medicine, Assiut University, Assiut, Egypt.

\title{
GONADAL AND EPIDIDYMAL SPERM COUNTS OF GROWING OSSIMI RAMS IN UPPER EGYPT
}

(With 3 Tables)

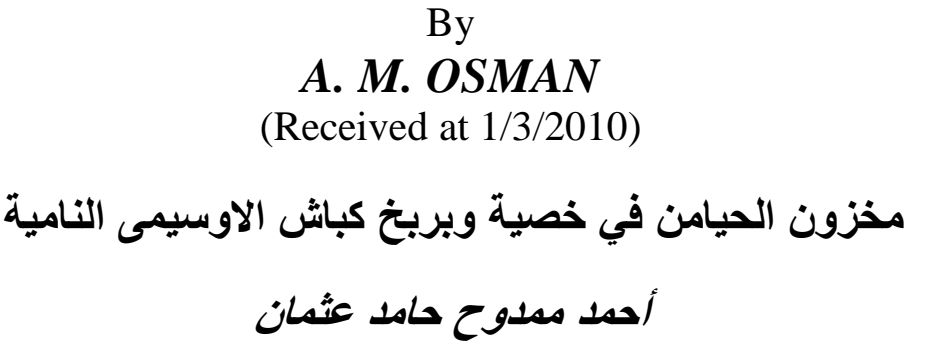

تم فى هذا البحث در اسة مخزون الحيامن بالخصبة و البربخ لعدد 48 ذوكر أوسيمى تراوحت

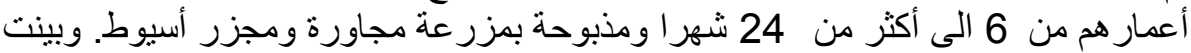

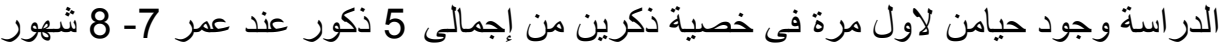

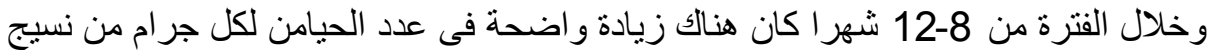

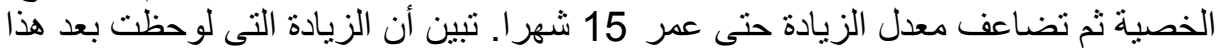

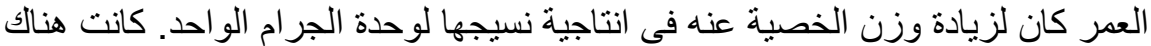

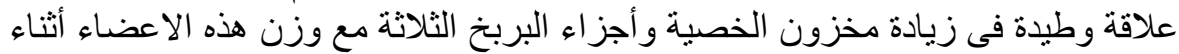

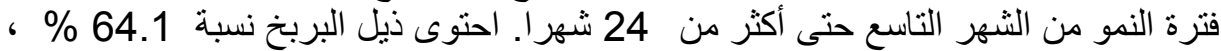

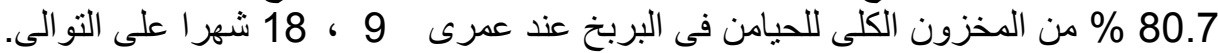

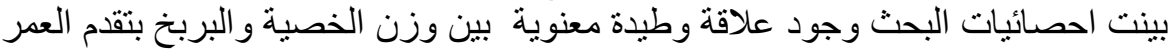

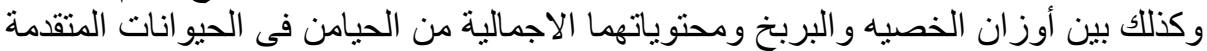
فى العمر خاصة بعد 18 شهر ا من العمر.

\section{SUMMARY}

Ossimi is the most abumdant breed of sheep in Egypt. As compared with other sheep, the age of puberty and reproductive capacity of this local breed received little attention. For both purposes, gonadal and epididymal sperm counts were studied in 48 healthy slaughtered growing Ossimi ram lambs. Animals were classified into 8 equal age groups $(6,7,8,12,15,18,24$ and $>24$ month). Testis and epididymis (caput, corpus and cauda) of one side were dissected and weighed separately. The whole testis and each region of epididymis were cut seperately into small pieces then homogenized with known volumes of saline using an electro mixer. To $5 \mathrm{ml}$ of each homogenate, 3 drops sodium hydroxide (2\%) and 2 drops eosin solution (3\%) were added and 
gently mixed. Stained sperm heads, without elongated spermatids, were counted twice with a cytometer. At 6 months, no sperm could be detected from any organ while at 7 months 2 cases had sperm in their testes only. In both cases testicular weight, sperm per g tissue and total sperm per gonad averaged $48.5 \mathrm{~g}, 23.6 \times 10^{6}$ and $1.14 \times 10^{9}$ sperm respectively. At 8 months, sperm were detected from all testes and epididymes. At this age, testis weighed $51.3 \pm 1.8 \mathrm{~g}$, while sperm count per $g$ tissue and per organ were $26.1 \pm 4.2 \times 10^{6}$ and $1.34 \pm 0.23 \times 10^{9}$ respectively. Moreove, total sperm count in epididymis was $1.64 \pm 0.19 \times 10^{9}$. After this age, testes and their total sperm counts showed significant increases $(\mathrm{P}<0.01)$ until 24 months. However, number of sperm per $\mathrm{g}$ tissue was maximum at earlier age ( 15 months) and reached $90.2 \pm 7.9 \times 10^{9}$. Epididymis (weight and total sperm) developed slowly from 7 to 12 months then rapidly until 24 months. Each region of epididymis grew independently. Ratios of caput and corpus weights to whole epididymis were $41.3 \%$ and $20 \%$ respectively at 8 months. These ratios decreased to $39.7 \%$ and $13.6 \%$ at 18 months, respectively. Ratios recorded for cauda increased from $38.7 \%$ to $46.7 \%$ at the same ages, respectively. There were similar trends for sperm counts. At 24 months, cauda contained $45.15 \pm 7.9 \times 10^{9}$ sperm representing $80.7 \%$ of total epididymal sperm. Significant correlations $(\mathrm{P}<0.01)$ were present between testis-epididymis weights and their sperm counts. It is evident that Ossimi ram lambs reached puberty at 7-8 months of age while maximum reproductive capacity attained at 2 years. Data obtained might be of value in rams selected for breeding especially with regard to evaluate the size of testes and cauda epididymedes.

Key words: Ossimi rams, testis, epididymis, sperm

\section{INTRODUCTION}

The number of sheep in Egypt reached 5.35 million (FAO, 2006). Moreover, Ossimi breed which originated in Ossim velllage, Giza Governorate, is the most popular among other breeds all over the country. They are subtropical fat tailed sheep, medium size and raised mainly under intensive cropping conditions to produce edible meat and coarse-carpet wool with colored fiberes (Mason, 1996). Breeding seasons are not present and usually 3 mating seasons per 2 years were managed (Almahdy et al., 2000).

Puberty in ram lambs ranged from 84-456 days depending on breed and body weight as cited by Haynes and Shanbacher (1983). The 
age of puberty in Ossimi and its crossbreeding with Chios french sheep was reported by Hassan et al. (1992) to be $296.8 \pm 35.4$ and $318.5 \pm 39.7$ days respectively depending upon the first appearance of sperm in the ejaclate. In Saidi ram lambs in Upper Egypt, Salem et al. (2005) determined the age of puberty, from the first detection of sperm in smear taken from the penile sheath, to be $363.8 \pm 13.3$ days at body weight of $50.3 \pm 3.0 \mathrm{~kg}$.

Knowledge about gonadal and extragonadal sperm reserves is of vital imprtance to assess the reproductive capacity of the male and as well the age of puberty. The available literature showed that Almquist and Amann (1961) were the first authors who determined the gonadal and extragonadal sperm reserves in cattle by dirct counts. Osman (1972) could modified the technique in buffalo bulls by adding $1 \%$ sodium hydroxide to the homogenate for clarification before counting and reported that gonadal sperm reserves in this species are lower than those in cattle. The sperm production rates were investigated in different breeds of sheep with variable results even within the same breed due to the variable applied techniques (Bielanski and Wierzbowski, 1961, Voglmayr et al., 1966, Abdo et al., 1978 and Queiroz and Cardoso, 1987).

Van Rooyen (2001) recommended that testes size is generally considered as an idirect measure of reproduction in ram. Moreover, Schoenian (2005) reported that most ram lambs reach puberty between 5 and 7 months of age at 50-60\% body weight. In Tanyang ram lambs, Cui et al. (2003) suggested that 4-5 months of age is a critical period for pubertal changes. Manson (2004) cited that sperm are stored in the epididymes particularly in its lower region, the tail, which can be felt by palpation as a large lump under each testis and a large firm tail indicates that the ram has good sperm reserves. In two adult Ossimi rams, Osman (1998) found that the total number of sperm in two exhaustion trials (11 and 13 ejaculates per trial respectively) represented $33.8 \%$ and $36.7 \%$ of the total sperm reserved in the cauda epididymides of both rams respectively after sexual rest and slaughter.

The aim of the present work is to study the quantification of gonadal and epididymal sperm reserves during the new pubertal period with regard to age and body weight in Ossimi rams to give an idea about their age of puberty and reproductive potential of their genitalia with the advance of age.

\section{MATERIALS and METHODS}


From a local farm and a slaughterhouse, the testes and epididymes of 48 growing Ossimi rams, with detrmined age and live body weight, were taken to the laboratory. All animals were healthy and their carcasses were fet for consumption. The testes and epididymes of each animal were taken to the laboratory. Each gonad was free from surrounding structures and dissected carefully from the connected epididymis, vas deferens and spermatic cord so as to leave the tunica albuginea intact. The corresponding epididymis was separated from the surrounding tissue and cut into 3 regions (head, body and tail). The testis and each region of the epididymis were weighed separately $(\mathrm{g})$.

The whole testis was cut into small pieces then homogenized with $500 \mathrm{ml}$ saline using an electromixer for 3-4 minutes according to Osman (!972). To $5 \mathrm{ml}$ of each homogenate 3 drops of sodium hydroxide (2\%) and 2 drops of eosin $(2 \%)$ were added and gently mixed. The addition of sodium hydroxide could clarify greatly the homogenate leaving the ovoid sperm heads and some remnant testicular tissues and faint elongated spermatids. The eosin-stained sperm heads could be easily differentiated and counted twice with a Thuma-rulling cytometer. The dilution rate was calculated for each trial from the ratio between the weight of orgran and volume of saline.

Each region of the epididymis was similarly treated but $200 \mathrm{ml}$ saline was used for tissue homogenization (Osman and El Azab, 1969). The dilution rates averaged about 1:10 for the testis and 1: 100 for each of the epididumal regions.

The results were expressed in Mean \pm SEM and correlations between two factors were statistically analysed according to Snedecor and Cochran (1980) and Pc-Stat (2003).

\section{RESULTS}

The obtained results are presented in Tables 1-3. As there were no marked differences between the characters of right and left testesepididymes, the results of only one side were taken into consideration. The live body weight showed a progressive increase with the advance of age till the end of study with significant correlation $(\mathrm{r}=0.9634)$ between them $(\mathrm{P}<0.01)$. However, maximum daily gain in body weight observed up to one year (143.3, 230 and $270 \mathrm{~g}$ between 6-7, 7-8 and 8-12 months respectively). After that age, the daily gain ranged between $28-51 \mathrm{~g}$.

On the other hand, the testes increased dramaticaaly after 8 month of age till 24 month only. The ratio of testes weight (both sides) 
to live body weigt increased sharply from $0.27 \%$ at 6 month of age to $0.69 \%$ at 2 years of age. Among different age groups $(6,7,8,12,15$, 18,24 and $>24$ months of age) the recorded ratios were $0.28,0.28,0.26$, $0.30,0.42,0.54,0.70$ and $0.58 \%$ respectively. Significant correlation between testes weight and body weight was present $(r=0.9267)$ among age groups $(\mathrm{P}<0.01)$.

It is noteworthy to mention that at 6 month of age no sperm could be detected from either the testes or epididymes of all individuals. At 7 month of age 2 out of 6 animals have sperm in their testes only. At 8 month of age, however, sperm could be detected from all testes and epididymes (Table 1) with some increase in live body weight and testes weight. Between 8 and 12 month of age, marked increase in the number of sperm per gram testicular tissue followed by double folds increase upto 15 month of age when no further increase could be observed. The steady increase in the total sperm count per gonad, after 12 month of age, coincides mainly with the pondreal increase observed in the testis weight which reached maximum value at two years.

The increase in weight and sperm count of the 3 epididymal regions was wariable with the advance of age (Table 2). From 8 to 24 month of age the rates of increase in caput, corpus and cauda epididymides weights were $3.3,2.4$ and 4.16 folds respectively. The corresponding values with regard to sperm per gram tissue and total sperm count per caput, corpus and cauda epididymides were 5.3, 8.5 and 10.3 (Sperm per gram tissue) and 17, 20.75 and 43 (total sperm count per region) folds respectively. It is evident from these results that each region of the epididymes grew independently from each other. In addition, the absolutely vast rates of increase were noticed with the cauda epididymides. The accumulation of sperm and epididymal secretion in this region, appeared associated with such high rate of development which observed for the cauda epididymydes in aged rams. It is of interrest to mention that most of the incised large cauda epididymedes in older Ossimi rams showed milky secretion which contained high concentration of motile sperm under the microscope after dilution with warm saline.

Table 3, showed the proportions in weights and total sperm reserves between the caput, corpus and cauda epididymides with the advance of age. The ratios of caput weight did not show any valuable changes with age but the ratios of corpus weight decreased from $20.4 \%$ to $13.9 \%$. On the other hand, the ratios of cauda epididymides weight increased from $40.7 \%$ (at 6 month of age) to $46.5 \%$ (at 24 month of 
age). With regard to the total sperm counts, the ratios decreased markedly in the caput (from $26.2 \%$ to $13.4 \%$ ) and corpus epididymides (from $9.7 \%$ to $6.0 \%$ ). The reverse was true with the cauda epididymides where marked increases were noticed in the ratios of sperm counts with the advance of age (from $64.1 \%$ at 8 month to 80.7 $\%$ at 24 month of age) as related to the total sperm counts in the whole epididymes.

The obtained data revealed the presence of significant correlations $(\mathrm{P}<0.01)$ between live body weight and epididymal $(\mathrm{r}=0.9088)$ weights among age groups. Moreover, significant correlations $(\mathrm{P}<0.01)$ were present between weights of testes and epididymes $(\mathrm{r}=0.9942)$ as well as between each of them and its total sperm count ( $\mathrm{r}=0.9939$ and $\mathrm{r}=0.9807$ respectively). The whole epididymes (weight) represents from $14 \%$ to $16 \%$ as related to the testes in all groups without significant difference with the advance of age.

Table 1: Testicular weight and sperm reserves as related to age and live body weight in slaughtered growing Ossimi ram.

\begin{tabular}{|c|c|c|c|c|}
\hline $\begin{array}{c}\text { Age Groups } \\
\text { (Month) }\end{array}$ & $\begin{array}{c}\text { Body Weight } \\
(\mathrm{Kg})\end{array}$ & $\begin{array}{c}\text { Testis Weight } \\
(\mathrm{g})\end{array}$ & $\begin{array}{c}\text { Sperm /g } \\
(\mathrm{x} 106)\end{array}$ & $\begin{array}{c}\text { Sperm/Organ } \\
(\mathrm{x} 109)\end{array}$ \\
\hline 6 & $28.2 \pm 4.3$ & $38.5 \pm 2.3$ & - & - \\
7 & $32.5 \pm 4.6$ & $46.3 \pm 2.8$ & $23.6(\mathrm{n}=2)$ & 1.14 \\
8 & $39.4 \pm 5.2$ & $51.3 \pm 1.8$ & $26.1 \pm 4.2$ & $1.34 \pm 0.23$ \\
12 & $47.5 \pm 4.8$ & $72.4 \pm 2.1$ & $40.8 \pm 2.8$ & $2.56 \pm 0.53$ \\
15 & $50.1 \pm 7.1$ & $106.0 \pm 2.2$ & $90.2 \pm 7.9$ & $9.56 \pm 0.53$ \\
18 & $54.7 \pm 6.9$ & $150.3 \pm 4.3$ & $90.0 \pm 7.9$ & $13.53 \pm 1.46$ \\
24 & $58.1 \pm 7.6$ & $201.2 \pm 7.8$ & $93.3 \pm 6.5$ & $18.77 \pm 2.01$ \\
$>24$ & $65.5 \pm 6.6$ & $190.2 \pm 6.6$ & $92.4 \pm 5.9$ & $17.57 \pm 2.11$ \\
\hline
\end{tabular}

$\mathrm{N}=6$ In each group

Mean \pm SEM 
Table 3: Proportions of weight and sperm reserves in the epididymal regions of slaughtered growing Ossimi rams

\begin{tabular}{|c|c|c|c|c|c|c|}
\hline \multirow{2}{*}{$\begin{array}{c}\text { Age Groups } \\
\text { (Months) }\end{array}$} & \multicolumn{2}{|c|}{ Caput Epididymidis } & \multicolumn{2}{c|}{$\begin{array}{c}\text { Corpus } \\
\text { Epididymidis }\end{array}$} & \multicolumn{2}{c|}{ Cauda pididymidis } \\
\cline { 2 - 7 } & $\begin{array}{c}\text { Weight } \\
\%\end{array}$ & $\begin{array}{c}\text { Sperm } \\
\%\end{array}$ & $\begin{array}{c}\text { Weight } \\
\%\end{array}$ & $\begin{array}{c}\text { Sperm } \\
\%\end{array}$ & $\begin{array}{c}\text { Weight } \\
\%\end{array}$ & $\begin{array}{c}\text { Sperm } \\
\%\end{array}$ \\
\hline 6 & 38.9 & - & 20.4 & - & 40.7 & - \\
7 & 40.9 & - & 19.7 & - & 39.4 & - \\
8 & 41.3 & 26.2 & 20.0 & 9.7 & 38.7 & 64.1 \\
12 & 41.2 & 25.0 & 16.7 & 7.2 & 42.1 & 67.8 \\
15 & 40.9 & 20.5 & 12.9 & 5.8 & 46.2 & 73.7 \\
18 & 39.7 & 13.7 & 13.6 & 5.6 & 46.7 & 80.7 \\
24 & 39.4 & 13.5 & 14.1 & 5.8 & 46.5 & 80.7 \\
$>24$ & 39.4 & 13.4 & 13.9 & 6.0 & 46.5 & 80.6 \\
\hline
\end{tabular}

\section{DISCUSSION}

Reviewing the literature of Watson et al. (1956), Skinner (1971), Dyrmundsson and Lees (1972) and Osman (1980), it is evident that Ossimi breed is smaller in size than other breeds (Merino, Dopper and Clun Forest). El Alamy et al. (1982) reported that Ossimi ram weighed $73.5 \mathrm{~kg}$ at 2 years of age, an average which is heigher than $58.1 \mathrm{~kg}$ reported here. On the other hand, Youssef and Saleem (1962) reported an average value of $25.0 \mathrm{~kg}$ for the body weight of twin males at 6 month of age which is slightly less than that recorded in the present work $(28.2 \pm 4.3 \mathrm{~kg})$. Individual variations and types of breeding may be responsible for such difference.

The average daily gain in body weight reported in the present work from 6-12 months of age (average $214.7 \mathrm{~g}$ ) is larger than $129 \mathrm{~g}$, at 8 months, as reported by Gueseous et al. (1998). The sharp decrease in daily gain after one year (43.3 g per day) denoted that Ossimi ram lambs achieved their mature size economically during their first year of life. It seems possible that the different levels of nutrition and managements of the studied ram lambs might be responsible for such differences in body 
weight gain and ram development in comparison with the results of ther authors.

The marked increase in the relative weight of testes to live body weight in Ossimi rams with age denoted higher rate of testicular development especially after 7-8 months (age of puberty). Morevoer, the rams posses the highest ratio between testes and live body weight in relation to other animals, $0.63 \%$ adult Ossimi rams versus $0.07 \%$ dairy bulls (Boyd and Van Demark, 1957) and $0.045 \%$ buffalo (Osman and Zaki, 1971). Manson (2004) cited that ram are 25 times as large, relative total weight, as human restes.

The age of puberty in Ossimi rams seems to start at 7 months of age where testicular sperm could be first detected in the tissue homogenates of 2 out of 6 ram lambs. Such age appeared delayed than 4-6 month reported by different authors in other foreign breeds of sheep (Rossouw and Grabbelaar (1975), Yarney and Sanford (1989), Madani et al. (1989) and Cui et al. (2003). On the other hand, Hassan et al. (1992) determined the age of Ossimi ram lambs at first ejaculation to be 9.9 months which is dlayed than that reported here (7-8 months). The absence of sperm in the epididymes of both Ossimi rams at 7 month of age denoted the presence of a transitional phase of about 4 weeks from the onset spermatogenesis till the appearance of sperm in the epididymes.

The number of sperm per gram testicular tissue in Ossimi rams did not show any increase after 15 month of age where the increase in total sperm counts were due to increase in testicular weight. Mcmillan and Hafs (1968) cithed that Holstein bulls attain their mature rate of spermatogenesis per gram testicular parenchyma by 1 year of age. Moreover, buffalo bulls attain such maximum rate by $2 \frac{1 / 2}{2}$ years of age (Osman 1972). Variations between species are expected with such criteria.

In comparison to other animals the rate of sperm production per gram of testicular homogenates is much higher in adult rams, 93.3 million in Ossimi rams versus 54.8 million dairy bulls (Almquist and Amann, 1961), 57.0 million buffalo bulls (Osman, 1972) and 47.2 million Egyptian camel (Osman and El Azab, 1974). However, Queiroz and Cardoso (1987) reported 111.4 million sperm per gram testis in Brazilian Hary rams which is higher than that found in Egyptian Ossimi rams.

The marked increase in total sperm counts in the testes and epididymes of Ossimi rams from 12 to 24 month of age, coincides 
greatly with the findings reported by Abdou et al. (1978) in Awasi rams. Osman (1998) reported triple fold increase in the size of Ossimi ram lambs testes-epididymes between 2 and 18 month of age and individuals which possessed larger testes- epididymes at early ages attained maximum gain in size during their growth. In the present study maximum reproductive capacity of Ossimi rams with regard to gonadal and epididymal size and their sperm counts attained at 24 months of age. In Magyar Tarka Bulls Osman (1970) reported that maximum development in the size of gonads reached at 8 years of age in animals more than 2 years old.

The storage capacity of the epididymes appeared to developed at a higher rapid rate than the capacity of the testes to produce or store sperm. From 12 to 24 month of age, the total sperm count increased from 2.56 to 18.77 and from 2.94 to 55.9 billions in the testis and epididymis respectively. Moreover, the cauda is the distinguished region of the epididymides to store sperm with the advance of age. Such heigher growth rate of the epididymes may occurred to accommodate the strong activity of the testes to produce sperm in rams. However, the presence of $80.7 \%$ of the total epididymal sperm in the cauda might reflect its peculiar role in the storage capacity. Osman (1998) reported that the total sperm numbers in two trials for exhaustion in Ossimi rams (13 and 11 consecutive semen collections per each trial) represent 33.8 $\%$ and $36.7 \%$ from the total sperm reserves in the couda epididemes respectively after rest and slaughter.

The data with regard to the presnce of significant correlations between live weight and testes weight as well as between the testes and epididymes and their sperm counts in Ossimi rams appeared in harmony with other investigators (Amann,1970, Osman, 1980, Madani et al., 1989 and Plant (2004).

As a amajor conclusion from the present work, Ossimi ram reached puberty at 7-8 months of age while maximum reproductive capacity achieved at 2 years. Data obtained may be of value in rams selected for breeding especially with regard to the size of testes and cauda epididymedes.

\section{RFERENCES}

Abdo, M.S.; Hassun, T.M. and El Sawaf, S.A. (1978): Testicular and epididymal sperm numbers and related parameters in the developing Awassi ram. Aust. J. Biol. Sci. 31, 3, 257. 
Al mahdy, H.; Tess, M.W.; El Tawil, E.; Shehata, E. and Mansour, H. (2000): Evaluation of Egyptian Sheep production systems: II. Breeding objectives for purebred and composite breeds. J, Anim. Sci. 78, 288.

Almquist, J.O. and Amann, R.P. (1961): Reproductive capacity of dairy bulls I. Gonadal and extragonadal sperm reserves as determined by direct count and depletion trials.; dimensions and weight of the genitalia. J. Dairy Sci. 44, 1668.

Amann, R.P. (1970): Sperm production rate. Chapter 7 in: The Testis, Vol 1 Academic Press INC., New York.

Bielanski, W. and Wierzbowski, S. (1961): Attempts at determination of the daily output of spermatozoa in rams on the basis of the so called ' depletion test' carried out at varying Intervals. Proc. $4^{\text {th }}$ Int. Congr. Anim. Reprod. and A.I., The Hague, 2, 274.

Boyd, L.J. and Van Demark, N.L. (1957): Spermatogenic capacity of the male bovine. I. A measurements technique. J. Dairy Sci. 40, 689.

Cui, S.; Chen, Y.F.; Yue, H.N.; He, Y.Q. and Mcneilly, A.S. (2003): Sexual development and the effects active immunization against GnRH in Chinese Tanyang ram lambs. Anim. Reprod. Sci. 77, 3-4, 129.

Dyrmundsson, O.R. and Lees, J.J. (1972): Pubertal development of Clun Forest ram lambs in relation To time pf birth J. Agric. Sci. UK, $79,83$.

Gueseous, F.; Boujenane, I.; Bourfia, M. and Narjisse, H. (1998): Small ruminants in the Near East. FAO, United Nations, Rome, Italy, paper 74.

El Alamy, M.A.; El Hommosi, F.F. and El Taweel, S.H. (1982): Number of stored spermayozoa and Its distribution in the genital tract of Ossimi and Saidi rams. Assiut J. Agric. Sci. 13, 5, 65.

FAO (2006): FAOSTAT, Statiasical Division, Agriculture and Livestock. Italy, Rome, 2009, 23 November.

Hassan, F.; Mousa, A.M.; Aboul Naga, M.M.; El Hommosi, F. and Abdel Hafez, G. (1992): Puberty and early mating performance in subtropical fat-tailed sheep and their crosses. Proc. $2^{\text {nd }}$ Biennial Conf. Afr. Small Ruminant Res. Network, AICC, Arusha, Tanzania, 7-11 December, 1992.

Haynes, N.B. and Schambacher, B.D. (1983): The control of reproductive capacity in the ram. In: Sheep Production. Haresign, W.Ed. Butterworths, London, pp 431-451. 
Mc Millan, K.L. and Hafs, H.D. (1968): Gonadal and epididymal sperm numbers during reproductive development of Hlstein bulls. J. Anim. Sci. 27, 697.

Madani, M.O.; Rahal, M.S.; Zawia, M.T. and Eluwhaishi, B.A. (1989): Puberty and early exual development in Libyan fat-tailed ram lambs. Br. Vet. J. 145, 3, 276.

Manson, D. (2004): Management of rams for mating. Fact Sheet internet explorer, www.pir.sa.gov.au/factsheet.

Mason, I.L. (1996): A World Dictionary of Livestock Breeds, Types and varieties. $4^{\text {th }}$ Ed.C.A.B. International, 273.

Osman, A.M. (1970): Clinical variations in testicular size of bulls older than two years. Zuchthyg., 5, 181.

Osman, A.M. and Zaki, K. (1971): Clinical and anatomical studies on the scrotum and its contents In buffaloes. Fortpfl. Haust. Bd. 7, S. 57-81.

Osman, A.M. (1972): Diagnostic studies on the gonadal sperm reserves in Buffalo bulls. Zbl. Vet. A, 19, 605.

Osman, A.M. (1980): Long term effects of bilateral vasectomy in immature lambs. Zbl. Vet. Med. A, 27, 392.

Osman, A.M. (1998): Clinical evaluation of testicular and epididymal size with regard to age and reproductive capacityt in Ossimi rams. Proc. $8^{\text {th }}$ World Conf. Anim. Prod. June 28 - July 4, Seoul, Korea.

Osman, A.M. and El Azab, E.A. (1969): Diagnostic studies on the extragonadal (epididymal) reserves of spermatozoa in water buffalo. Acta Vet. Acad. Sci. Hungaricae, 19, 4, 363.

Osman, A.M. and El Azab E.A. (1974): Gonadal and epididymal sperm reserves in the camel, Camelus Dromedarius. J. Reprod. Fert. $38,425$.

Pc-Stat (2003): Computer Program of Statistical Analysis, Micro Office Excell, 2003.

Plant, J.W. (2004): Fertility testing of rams. www.agric.nsw.gov.au.

Queiroz, G. and Cardoso, F.M. (1987): Testicular and epididymal sperm reserves of Brazilian hairy rams. J.Vet. Med. A, 34, 657.

Rossouw, A.F. and Grabbelaar, J.A.N. (1975): Post-partum growth and development of the reproductive tract of the Karakul ram. S. Afr. J. Anim. Sci. 5, 3, 42. 
Salem, A.A.; Salem, I.A. and Aboulwafa, G. (2005): Relationship of puberty and semen characteristics to seasonal and nutritional variations in Saidi ram lambs. Egyptian J. Anim. Prod. 42, 2, 145 .

Schoenian, S. (2005): Reproduction in the ram. Maryland Coop. Ext.Univ., Maryland, 21, 41.

Skinner, J.D. (1971): Compensatory testicular hyperatrophy and hypotrophy of the homolateral ampulla following unilateral orchidoctomy in adult ram. . Agroanimalia, 397.

Snedecor, G.W. and Cochran, W.C. (1980): Statistical Methods. 7th ed., Iowa State Univ. Press. Ames, USA.

Van Rooyen, J.A. (2001): How many ewes to a ram? Nat. Wool. Gr. Ass., South Africa, November.

Voglmayr, J.K.; Waites, J.M.H. and Setchell, B.P. (1966): Studies on spermatozoa and fluid collected directly from the testes of the conscious ram. Nature, Lond. 210, 861.

Watson, R.H.; Sapsford, C.S. and McCance, T. (1956): The development of the testis, epididymis and penis in the young Merino rams. Aust. J. Agric. Res. 7, 374.

Yarney, T.A. and Sanford, L.M. (1989): Pubertal changes in the secretion of gonadotropine Hormones, testicular gonadotropic receptors and testicular function in the ram. Dom. Anim. Endocrinol, 6, 3, 219.

Youssef, A.A. and Saleem, M.Z. (1962): Some factors affecting selection in the Ossimi and Rahmani flocks. J. Anim. Prod. A.R. Egypt, $2,2,77$. 
Assiut Vet. Med. J. Vol. 56 No. 125 April 2010 
Table 2: Epididymal regions weight and sperm reserves as related to age in slaughtered growing Ossimi rams

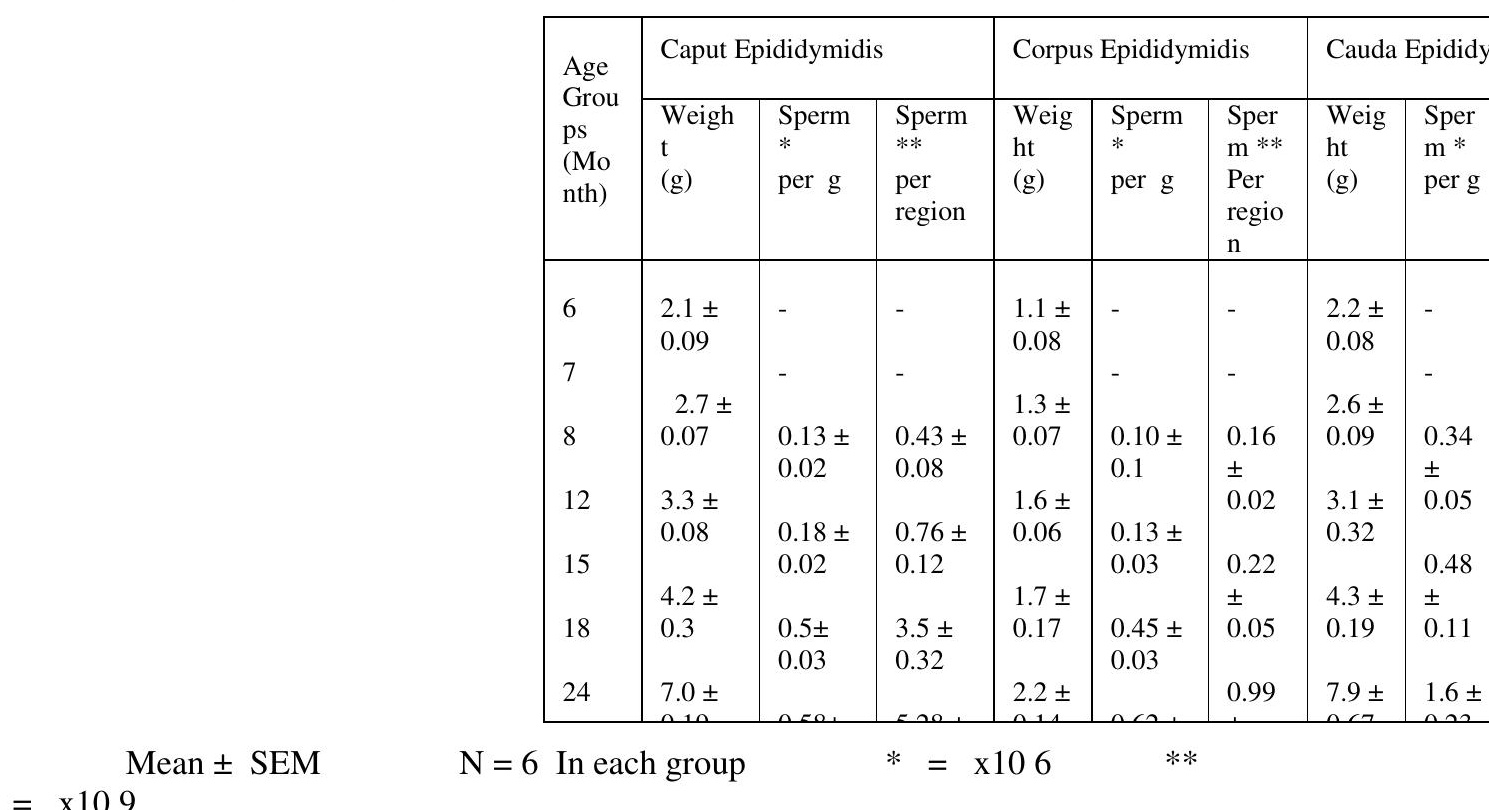


Assiut Vet. Med. J. Vol. 56 No. 125 April 2010 
Assiut Vet. Med. J. Vol. 56 No. 125 April 2010 